\title{
Streptomyces polyantibioticus sp. nov., isolated from the banks of a river
}

Correspondence

Paul R. Meyers

paul.meyers@uct.ac.za
Marilize le Roes-Hillt and Paul R. Meyers

Department of Molecular and Cell Biology, University of Cape Town, Private Bag 1, Rondebosch 7701, Cape Town, South Africa

As part of an antibiotic-screening programme, an actinomycete, designated strain $\mathrm{SPR}^{\top}$, was isolated from soil collected from the banks of the Umgeni River, KwaZulu-Natal Province, South Africa. The isolate produced branching vegetative mycelia with sporangiophores bearing sporangia developing at a late stage of growth. The sporangia contained smooth, almond-shaped, non-motile spores. Strain SPR ${ }^{\top}$ exhibited antibiosis against various Gram-positive and Gramnegative bacteria, including Enterococcus faecium VanA (a vancomycin-resistant strain), Mycobacterium aurum A+ and Escherichia coli ATCC 25922. The chemotaxonomic characteristics of the strain, with the exception of the phospholipid pattern, corresponded with those of the members of the family Streptomycetaceae Waksman and Henrici 1943. Furthermore, phylogenetic analysis based on 16S rRNA genes showed that the strain was closely related to members of the genus Streptomyces, which supports its classification in the family Streptomycetaceae. Thus strain SPR ${ }^{\top}$ represents a novel species of the genus Streptomyces, for which the name Streptomyces polyantibioticus sp. nov. is proposed. The type strain is SPR $\left(=\mathrm{DSM} 44925^{\mathrm{T}}=\right.$ NRRL B-24448 $\left.{ }^{\mathrm{T}}\right)$.
Tuberculosis has become the leading cause of natural death in South Africa, killing 218 per 100000 people in the population per annum, striking most victims in their most economically productive years. South Africa is one of the 22 most burdened countries in the world (listed fourth) for this disease, having an average incidence rate of 940 tuberculosis cases per 100000 people in the population per annum (WHO, 2008). To compound the problem, it is estimated that $44 \%$ of all tuberculosis patients are also positive for the human immunodeficiency virus $(50 \%$ in 2003; $61 \%$ in 2005; WHO, 2008).

The genus Streptomyces was first described by Waksman \& Henrici (1943). After a period of classification and reclassification of genera such as Actinopycnidium, Actinosporangium, Chainia, Elytrosporangium, Microellobosporia, Kitasatoa and Streptoverticillium (Anderson \& Wellington, 2001), the genus Streptomyces now consists of more than 540 species with validly published names (Euzéby, 2008). The systematics of the genus Streptomyces at species level, however, is still in a state of confusion and

†Present address: Biocatalysis and Technical Biology Research Group, Cape Peninsula University of Technology, Bellville Campus, PO Box 1906, Bellville 7535, Cape Town, South Africa.

The GenBank/EMBL/DDBJ accession number for the 16S rRNA gene sequence of strain $\mathrm{SPR}^{\top}$ is DQ141528.

A Southern blot showing the rRNA operon copy number of strain SPR ${ }^{\top}$ is available as a supplementary figure with the online version of this paper. the genus is believed to be overspeciated (having by far the highest number of species with validly published names) (Groth et al., 1999).

As part of a screening programme for antitubercular antibiotic-producing actinomycetes, an actinomycete with unusual morphology was isolated from soil collected from the banks of the Umgeni River (KwaZulu-Natal Province, South Africa).

Strain $\mathrm{SPR}^{\mathrm{T}}$ was isolated on Middlebrook $7 \mathrm{H} 9$ agar (Becton Dickinson; supplemented with $10 \mathrm{mM}$ glucose; albumin-glucose-catalase supplement omitted) after incubation at $28{ }^{\circ} \mathrm{C}$ for 7 days. Following isolation, strain $\mathrm{SPR}^{\mathrm{T}}$ was maintained on Middlebrook 7H9-glucose agar.

Antimicrobial activity was determined using the sloppyagar overlay technique, whereby the isolate was stabinoculated with sterile toothpicks into Middlebrook 7H9glucose, Czapek solution (Atlas, 2004) and yeast extractmalt extract (ISP 2 medium; Shirling \& Gottlieb, 1966) agar plates, in duplicate. Plates were incubated for 10 days at $30{ }^{\circ} \mathrm{C}$ (and the duplicate set at $37{ }^{\circ} \mathrm{C}$ ) and overlaid with $6 \mathrm{ml}$ Luria sloppy agar (Sambrook et al., 1989) containing the test bacterium. Activity was tested against various Gram-positive and Gram-negative bacteria.

Strain $\mathrm{SPR}^{\mathrm{T}}$ was cultured in $500 \mathrm{ml}$ Hacène's medium (containing, $1^{-1}$ distilled water: $5.0 \mathrm{~g}$ glucose, $4.0 \mathrm{~g}$ yeast extract, $10.0 \mathrm{~g}$ malt extract and $1.0 \mathrm{~g} \mathrm{NaCl}, \mathrm{pH}$ 7.0; Hacène \& Lefebvre, 1995) for 10 days at $30{ }^{\circ} \mathrm{C}$ on a rocking shaker. 
The culture was filtered through a coffee filter $(1 \times 4$-sized filters; House of Coffees). The mycelial mass of the isolate was extracted with methanol and the antibacterial activity was determined by means of bioautography (Betina, 1973).

The morphological characteristics of strain $\mathrm{SPR}^{\mathrm{T}}$ were determined using standard methods (Locci, 1989). The isolate was grown on Middlebrook 7H9-glucose agar for 19, 63 and 90 days at $30{ }^{\circ} \mathrm{C}$ and the morphology was observed under a light microscope and by cryo-scanning electron microscopy.

Standard physiological tests were performed as described by Locci (1989). ISP media were prepared as described by Shirling \& Gottlieb (1966). Antibiotic resistance was determined by incorporating antibiotics into Bennett's medium agar plates (Atlas, 2004) at the recommended concentrations (Locci, 1989). The concentrations of the non-standard test antibiotics were as follows: capreomycin $\left(20 \mu \mathrm{g} \mathrm{ml}^{-1}\right)$, cefotaxime $\left(100 \mu \mathrm{g} \mathrm{ml}^{-1}\right)$, D-cycloserine $\left(50 \mu \mathrm{g} \mathrm{ml}^{-1}\right)$, kanamycin $\left(10 \mu \mathrm{g} \mathrm{ml}^{-1}\right)$ and viomycin $\left(8 \mu \mathrm{g} \mathrm{ml}^{-1}\right)$. Physiological characteristics were determined after growth at $30{ }^{\circ} \mathrm{C}$ (unless otherwise stated) for the recommended incubation periods. All carbon sources used for carbon-utilization tests were filter-sterilized and tested at the concentrations recommended by Locci (1989) and Shirling \& Gottlieb (1966). Utilization of organic acids and resistance to lysozyme were determined as described by Gordon et al. (1974).

Standard techniques were used for the determination of catalase and oxidase activities. Staining was performed using the standard Gram-staining technique. Acid-fast staining (with $1 \%$ sulphuric acid in the decolorization step) and acid-alcohol-fast staining (Ziehl-Neelsen) were performed using standard methods.

The freeze-dried cells used in chemotaxonomic tests were obtained from a $500 \mathrm{ml}$ ISP 2 culture of strain $S P R^{\mathrm{T}}$, which was cultivated on a rocking shaker at $30{ }^{\circ} \mathrm{C}$ for 5 days. The diaminopimelic acid isomer and the whole-cell sugar pattern were determined using the method of Hasegawa et al. (1983), with the exception that freeze-dried cells were used instead of colonies from agar plates.

The fatty acid methyl esters were prepared according to Chou et al. (1998) and were analysed by GC on a Zebron GC column (ZB-1; $0.25 \mathrm{~mm}$ by $30 \mathrm{~m}$ ). The temperature of the column was fixed at $210{ }^{\circ} \mathrm{C}$ and the temperature of the injector was programmed to increase from 150 to $220{ }^{\circ} \mathrm{C}$ at a rate of $4{ }^{\circ} \mathrm{C} \mathrm{min}^{-1}$. The peaks were identified by means of comparison with fatty acid methyl ester standards (MIX GLC-80; Supelco). Mycolic acids were isolated and analysed as described by Minnikin et al. (1975). Phospholipids were isolated as described by Minnikin et al. (1984) and analysed by two-dimensional TLC on silica gel $60 \mathrm{~F}_{254}$ (Merck) plates, as described by Komagata \& Suzuki (1987). Menaquinones were analysed by the Identification Service of the Deutsche Sammlung von Mikroorganismen und Zellkulturen (Braunschweig,
Germany), using an HPLC separation method. The peptidoglycan type was determined as described by Komagata \& Suzuki (1987): TLC was used for the analysis. The $\mathrm{G}+\mathrm{C}$ content of the DNA was determined in $1.0 \times$ SSC by using the thermal denaturation method described by Mandel \& Marmur (1968).

The 16S rRNA gene was amplified using PCR with the bacterial 16S rRNA gene primers F1 (Cook \& Meyers, 2003) and R6 5'-AAGGAGGTGITCCAICC-3' [modified from primer p1525r of Chun \& Goodfellow (1995); $\mathrm{I}=$ inosine]. PCR conditions were as described by Cook \& Meyers (2003). The amplified DNA was purified for sequencing using a QIAquick PCR purification kit (Qiagen). For the phylogenetic analysis, reference strains were chosen from the BLAST results (Altschul et al., 1997) and the top hits from the identity analysis of the EzTaxon server (Chun et al., 2007). For the construction of phylogenetic trees, the software package MEGA (version 3.1; Kumar et al., 2004; http://www.megasoftware.net/) was used. Unrooted phylogenetic trees were constructed using the neighbour-joining (Saitou \& Nei, 1987), minimumevolution and maximum-parsimony methods (Takahashi \& Nei, 2000) and then evaluated by means of bootstrap resampling (based on 1000 replications).

Genomic DNA was digested singly with restriction endonucleases: SalI and ScaI for the determination of $16 \mathrm{~S}$ rRNA operon multiplicity, and SalI, EcoRV, SspBI and SnaBI for the determination of 23S rRNA operon multiplicity. The digested genomic DNA was electrophoresed on a $0.7 \%$ agarose gel for $24 \mathrm{~h}$. Copy numbers for both the 16S rRNA gene and the 23S rRNA gene were determined by means of Southern hybridization (Sambrook et al., 1989). DNA probes labelled with digoxigenin-dUTP (Roche) were used. The probe for the determination of the $16 \mathrm{~S}$ rRNA copy number was amplified from strain $\mathrm{SPR}^{\mathrm{T}}$ by using the universal bacterial primers F1 and R5 (Cook \& Meyers, 2003). The probe for the determination of the $23 \mathrm{~S}$ rRNA copy number was amplified using the primers described by Wang \& Zhang (2000): forward primer 5'-CCGATGAAGGACGTGGGA3' (positions 46-63; numbering according to the Streptomyces ambofaciens ATCC $23877^{\mathrm{T}} 23 \mathrm{~S}$ rRNA gene) and reverse primer 5'-ACCAGTGAGCTATTACGC-3' (positions 1212-1195; numbering according to the $S$. ambofaciens ATCC $23877^{\mathrm{T}} 23 \mathrm{~S}$ rRNA gene; the last three nucleotides of the published primer were modified from GCG to CGC). Amplified, unlabelled 16S rDNA and 23S rDNA were used as positive controls. Hybridization and visualization were performed as recommended in the Roche DIG manual (http://www.roche.com).

From cryo-scanning electron microscopy (Fig. 1), it was clear that the strain goes through various stages of morphological development. After 19 days growth, Rectiflexibiles-type spore-chain morphology with smooth spores was clearly visible (Fig. 1a). After 63 days growth, the first signs of sporangium formation became apparent 

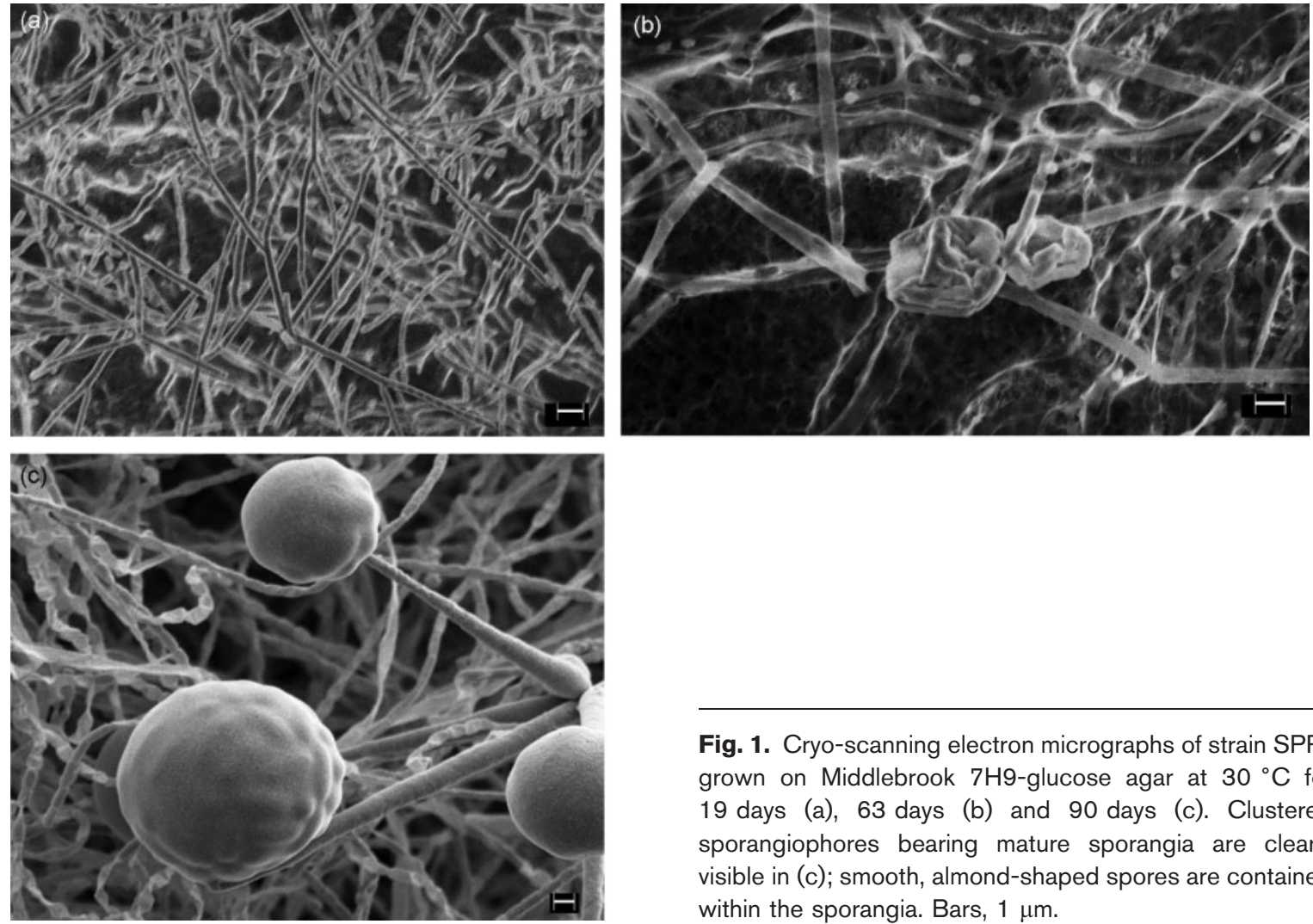

Fig. 1. Cryo-scanning electron micrographs of strain $\mathrm{SPR}^{\top}$ grown on Middlebrook $7 \mathrm{H} 9$-glucose agar at $30{ }^{\circ} \mathrm{C}$ for 19 days (a), 63 days (b) and 90 days (c). Clustered sporangiophores bearing mature sporangia are clearly visible in (c); smooth, almond-shaped spores are contained within the sporangia. Bars, $1 \mu \mathrm{m}$.

(Fig. 1b). After 90 days growth, sporangia borne on clustered sporangiophores were clearly visible (Fig. 1c). Straight-to-flexuous chains of spores were still visible at 90 days (this is not clearly shown in Fig. 1c). The spore sacs produced are clearly different from the pseudosporangia (which lack a surrounding membrane) observed in the two members of the now-defunct genus Actinosporangium, namely Actinosporangium violaceum and Actinosporangium vitaminophilum (now named Streptomyces paradoxus and Streptomyces vitaminophilus, respectively). Smooth, almond-shaped spores were visible within the sporangia. The sporangiophores were typically $11-18 \mu \mathrm{m}$ long, the sporangia were $6-10 \mu \mathrm{m}$ in diameter and the spores were approximately $2 \mu \mathrm{m}$ long. The sporangiophores and sporangia had a 'lollipop' appearance and clustered in groups of four to six (Fig. 1c). When plates containing mature sporangia were flooded with water, no spore motility was observed under a light microscope.

A comparison of the chemotaxonomic characteristics of strain $\mathrm{SPR}^{\mathrm{T}}$ with those of members of the sporangiate genera and the phylogenetically related non-sporangiate genera Streptomyces and Kitasatospora is shown in Table 1. LL-Diaminopimelic acid and glycine were detected in an amino acid analysis of strain $S R^{\mathrm{T}}$ and the whole-cell sugar hydrolysate yielded galactose and glucose, with traces of ribose and mannose. Mycolic acids were not detected and the peptidoglycan was of the A3 $\gamma$ type [LL-diaminopimelic acid and glycine, as determined by TLC; Schleifer \&
Kandler (1972)]. The predominant fatty acids were iso- and anteiso-branched (28\% iso- $\mathrm{C}_{16: 0} ; 18 \%$ anteiso- $\mathrm{C}_{15: 0} ; 15 \%$ $\mathrm{C}_{16: 0} ; 14 \%$ anteiso- $\mathrm{C}_{17: 0} ; 10 \%$ iso- $\mathrm{C}_{15: 0} ; 8 \%$ iso- $\left.\mathrm{C}_{17: 0}\right)$, the profile being similar to those observed for Streptomyces strains. Phosphatidylglycerol, phosphatidylethanolamine, diphosphatidylglycerol, phosphatidylinositol, phosphatidylinositol mannoside and two unknown phospholipids were detected by means of two-dimensional TLC analysis. The predominant menaquinones were $\mathrm{MK}-9\left(\mathrm{H}_{4}\right)(60 \%)$ and MK-9 $\left(\mathrm{H}_{6}\right)(40 \%)$; traces of MK-9 $\left(\mathrm{H}_{2}\right)(<3 \%)$ were also detected. The DNA G $+\mathrm{C}$ content was $74.4 \pm 0.2 \mathrm{~mol} \%$ when determined (in duplicate) in $1.0 \times$ SSC.

A 1459 bp 16S rRNA gene sequence was obtained for strain $\mathrm{SPR}^{\mathrm{T}}$. A BLAST search revealed $98 \%$ sequence similarity with respect to Streptomyces cavourensis subsp. cavourensis NBRC $13026^{\mathrm{T}}(97.88 \%$ by pairwise local alignment in DNAMAN, version 4.13; Lynnon BioSoft), Streptomyces caviscabies ATCC $51928^{\mathrm{T}}(97.03 \%$ in DNAMAN $)$ and Streptomyces setonii ATCC $25497^{\mathrm{T}}$ (97.03\% in DNAMAN) and various other members of the genus Streptomyces. A search of the EzTaxon server revealed $99.5 \%$ pairwise sequence similarity with respect to $S$. cavourensis subsp. cavourensis NBRC $13026^{\mathrm{T}}(97.88 \%$ in DNAMAN), Streptomyces albolongus NBRC $13465^{\mathrm{T}}(97.81 \%$ in DNAMAN), Streptomyces celluloflavus NBRC $13780^{\mathrm{T}}$ $(97.81 \%$ in DNAMAN) and $99.4 \%$ pairwise sequence similarity with respect to Streptomyces griseobrunneus NBRC $12775^{\mathrm{T}}$ ( $97.81 \%$ in DNAMAN). A phylogenetic tree 
Table 1. Comparison of chemotaxonomic characteristics of strain $\mathrm{SPR}^{\top}$, sporangiate genera and the genus Streptomyces

Taxa: 1, Actinomadura; 2, Actinoplanes; 3, Dactylosporangium; 4, Planomonospora; 5, Planobispora; 6, Spirillospora; 7, Streptosporangium; 8, Streptomyces; 9, Kitasatospora; 10, strain SPR ${ }^{\mathrm{T}}$ (Streptomyces polyantibioticus sp. nov.). Data are from Goodfellow (1989) and Locci (1989); data for the genus Kitasatospora are from Chung et al. (1999) and Groth et al. (2003). None of the genera possesses mycolic acids.

\begin{tabular}{|c|c|c|c|c|c|c|c|c|c|c|}
\hline Characteristic & 1 & 2 & 3 & 4 & 5 & 6 & 7 & 8 & 9 & 10 \\
\hline $\begin{array}{l}\text { Diagnostic amino } \\
\text { acid }^{*}\end{array}$ & meso-DAP & meso-DAP + glycine & $\begin{array}{c}\text { meso- } \\
\mathrm{DAP}+\text { glycine }\end{array}$ & meso-DAP & meso-DAP & meso-DAP & meso-DAP & $\begin{array}{c}\text { LL- } \\
\text { DAP + glycine }\end{array}$ & $\begin{array}{l}\text { LL-DAP and } \\
\text { meso-DAP }\end{array}$ & $\begin{array}{l}\text { LL-DAP } \\
+ \text { glycine }\end{array}$ \\
\hline Diagnostic sugars & Madurose & Xylose + arabinose & $\begin{array}{c}\text { Xylose }+ \text { arabin- } \\
\text { ose }\end{array}$ & Madurose & Madurose & Madurose & Madurose & $\begin{array}{l}\text { No diagnostic } \\
\text { sugars }\end{array}$ & Galactose & $\begin{array}{c}\text { No diagnostic } \\
\text { sugars }\end{array}$ \\
\hline Phospholipid pattern $\dagger$ & PI & PII & PII & PIV & PIV & PI, PII & PIV & PII & PII & $\begin{array}{c}\text { PG, PE, PI, } \\
\text { PIM and } \\
\text { DPG§ }\end{array}$ \\
\hline Menaquinone pattern & MK-9 $\left(\mathrm{H}_{4}, \mathrm{H}_{6}, \mathrm{H}_{8}\right)$ & $\begin{array}{c}\text { MK-9 }\left(\mathrm{H}_{4}\right), \text { MK- } \\
10\left(\mathrm{H}_{4}\right)\end{array}$ & $\begin{array}{c}\text { MK- } \\
9\left(\mathrm{H}_{4}, \mathrm{H}_{6}, \mathrm{H}_{8}\right)\end{array}$ & MK-9 $\left(\mathrm{H}_{0}, \mathrm{H}_{2}, \mathrm{H}_{4}\right)$ & $\begin{array}{c}\text { MK- } \\
9\left(\mathrm{H}_{2}, \mathrm{H}_{4}\right)\end{array}$ & $\begin{array}{c}\text { MK- } \\
9\left(\mathrm{H}_{4}, \mathrm{H}_{6}\right)\end{array}$ & MK-9 $\left(\mathrm{H}_{2}\right)$ & $\begin{array}{c}\text { MK- } 9\left(\mathrm{H}_{6} \text { or }\right. \\
\left.\mathrm{H}_{8}\right)\end{array}$ & $\begin{array}{c}\text { MK- } \\
9\left(\mathrm{H}_{2}, \mathrm{H}_{4}, \mathrm{H}_{6}\right)\end{array}$ & MK-9 $\left(\mathrm{H}_{4}, \mathrm{H}_{6}\right)$ \\
\hline $\begin{array}{l}\text { DNA G }+\mathrm{C} \text { content } \\
(\mathrm{mol} \%)\end{array}$ & $65-77$ & $72-73$ & $71-73$ & 72 & $70-71$ & $71-73$ & $69-71$ & $69-78$ & $69-76$ & 74 \\
\hline
\end{tabular}

${ }^{*}$ DAP, 2,6-diaminopimelic acid.

†Phospholipid pattern: PI, phosphatidylglycerol; PII, phosphatidylethanolamine; PIII, phosphatidylcholine (with variable proportions of phosphatidylethanolamine, phosphatidylmethylethanolamine and phosphatidylglycerol); PIV, phospholipids containing glucosamine (with variable proportions of phosphatidylethanolamine and phosphatidylmethylethanolamine).

\#Fatty acid pattern: $2 c$, iso- and anteiso-branched and saturated fatty acids; 3a, saturated, unsaturated, iso- (variable) and methyl-branched fatty acids; $3 c$, saturated, unsaturated, iso-, anteiso(variable) and methyl-branched fatty acids.

§DPG, Diphosphatidylglycerol; PE, phosphatidylethanolamine; PG, phosphatidylglycerol; PI, phosphatidylinositol; PIM, phosphatidylinositol mannoside. 
of strain $\mathrm{SPR}^{\mathrm{T}}$, streptomycete strains and the type species of the genera Kitasatospora and Streptacidiphilus (Fig. 2) showed that the strain clustered with the type strain of Streptomyces mauvecolor and other members of the genus Streptomyces. The 16S rRNA gene sequence similarity between strain $\mathrm{SPR}^{\mathrm{T}}$ and S. mauvecolor was $98.80 \%$ (by pairwise local alignment in DNAMAN). Phylogenetically, therefore, strain $\mathrm{SPR}^{\mathrm{T}}$ clearly belongs to the genus Streptomyces. Table 2 lists phenotypic differences between strain $\mathrm{SPR}^{\mathrm{T}}$ and its closest phylogenetic relatives.

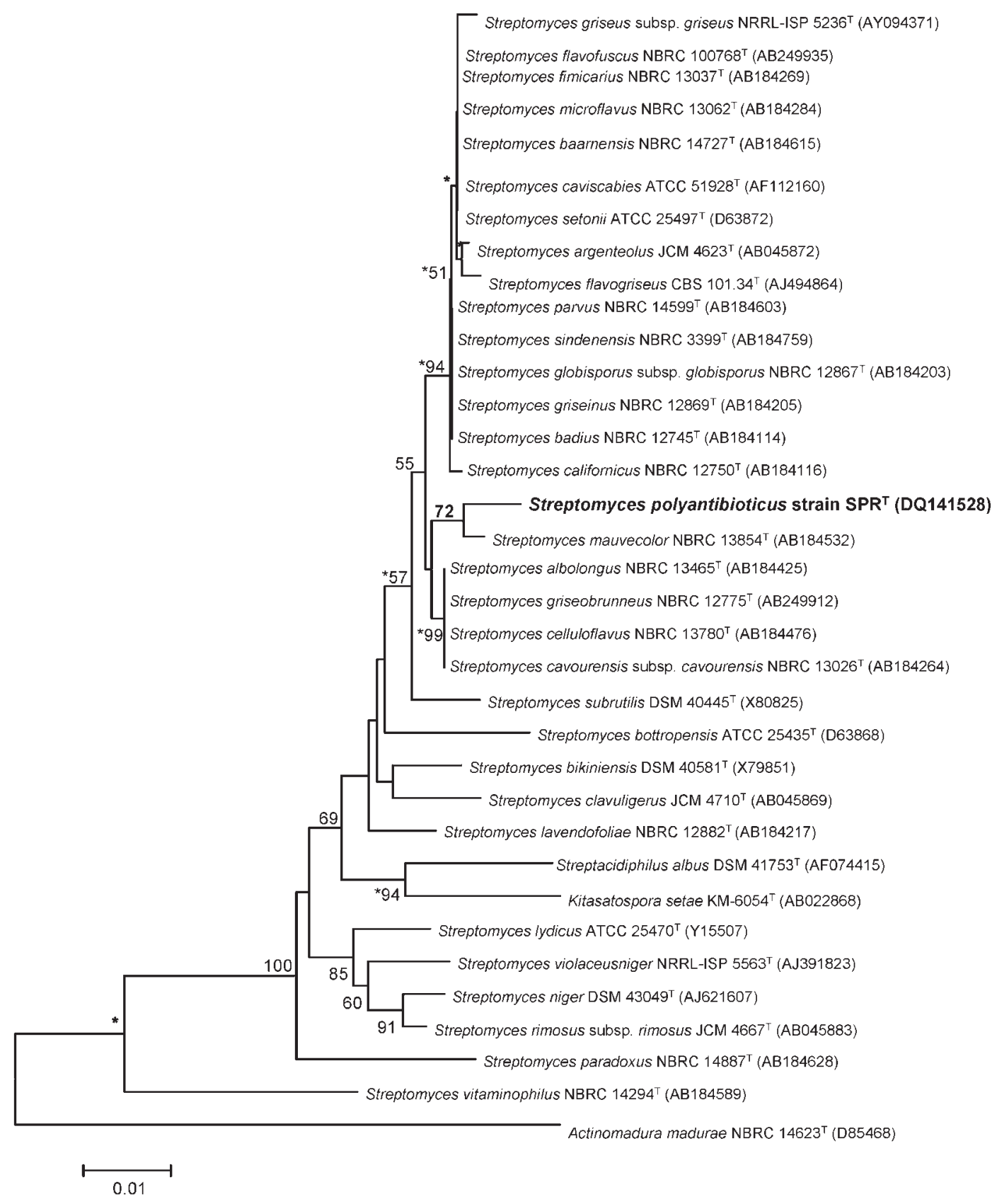

Fig. 2. Unrooted, neighbour-joining phylogenetic tree, based on $16 \mathrm{~S}$ rRNA gene sequences, showing the position of strain $\mathrm{SPR}^{\top}$ among its phylogenetic neighbours. The $16 \mathrm{~S}$ rRNA gene sequence of Actinomadura madurae NBRC $14623^{\top}$ was used as an outgroup. All sequences were edited to the longest common region (1409 bp). GenBank sequence accession numbers are given in parentheses. Bootstrap percentages (based on 1000 replications) are shown at the nodes. Asterisks indicate clades that were conserved in neighbour-joining, minimum-evolution and maximum-parsimony trees. Bar, 1 nucleotide substitution per 100 nt. 
Table 2. Comparison of phenotypic characteristics of strain $\mathrm{SPR}^{\top}$ with those of Streptomyces species

Strains: 1, strain SPR ${ }^{\mathrm{T}}$; 2, S. mauvecolor NBRC $13854^{\mathrm{T}}$ (data from Locci, 1989); 3, S. albolongus NBRC 23465 ${ }^{\mathrm{T}}$ (Shirling \& Gottlieb, 1972); 4, S. cavourensis subsp. cavourensis NBRC $13026^{\mathrm{T}}$ (Skarbek \& Brady, 1978). W+, Weakly positive; ND, not determined.

\begin{tabular}{|c|c|c|c|c|}
\hline Phenotypic characteristic & 1 & 2 & 3 & 4 \\
\hline Spore-chain morphology & Rectiflexibiles; sporangia & Spirales & Rectiflexibiles & Rectiflexibiles \\
\hline Spore-surface ornamentation & Smooth & Spiny & Smooth & Smooth \\
\hline Colour of substrate mycelium & Dark brown & $\mathrm{ND}$ & Yellow-brown & Yellow-brown \\
\hline \multicolumn{5}{|l|}{ Utilization as sole carbon source } \\
\hline L-Arabinose & - & + & + & $\mathrm{w}+$ to + \\
\hline myo-Inositol & + & - & - & - \\
\hline Raffinose & + & + & - & - \\
\hline Salicin & + & + & ND & ND \\
\hline D-Xylose & + & - & + & + \\
\hline
\end{tabular}

Strain $\mathrm{SPR}^{\mathrm{T}}$ contains seven copies of the $16 \mathrm{~S}$ and $23 \mathrm{~S}$ rRNA genes (see Supplementary Fig. S1, available in IJSEM Online). Copy numbers of four or more have been detected in soil actinomycetes; this is not surprising, as Klappenbach et al. (2000) showed that a high rRNA gene copy number confers an advantage in fluctuating environments (such as soil), where it ensures an ability to utilize newly introduced resources quickly.

The chemical and phylogenetic characteristics of strain $\mathrm{SPR}^{\mathrm{T}}$ were similar to those of members of the genus Streptomyces. The predominant menaquinones observed for strain SPR ${ }^{\mathrm{T}}$ were MK-9 $\left(\mathrm{H}_{4}, \mathrm{H}_{6}\right)$; this profile differs from that of most streptomycetes [which contain MK-9 $\left(\mathrm{H}_{6}, \mathrm{H}_{8}\right)$ ], but matches that of members of the genus Actinomadura. The tetrahydrogenated MK-9 menaquinone has been detected in some streptomycetes, including Streptomyces hebeiensis DSM $41837^{\mathrm{T}}$ (Xu et al., 2004), Streptomyces scabrisporus NRRL B-24202 ${ }^{\mathrm{T}}$ (Ping et al., 2004), Streptomyces scopiformis $\mathrm{A} 25^{\mathrm{T}}$ (Li et al., 2002), Streptomyces sodiiphilus CIP $107975^{\mathrm{T}}$ (Li et al., 2005), Streptomyces thermocoprophilus $\mathrm{B} 19^{\mathrm{T}}$ (Kim et al., 2000) and Streptomyces yeochonensis NRRL B-24245 (Kim et al., 2004). With the exception of S. scabrisporus NRRL B$24202^{\mathrm{T}}$, none of these streptomycetes has MK-9 $\left(\mathrm{H}_{4}\right)$ as the predominant menaquinone.

On the basis of the results of the polyphasic taxonomic analysis described here, strain $\mathrm{SPR}^{\mathrm{T}}$ represents a novel species of the genus Streptomyces, for which the name Streptomyces polyantibioticus sp. nov. is proposed.

\section{Description of Streptomyces polyantibioticus sp. nov.}

Streptomyces polyantibioticus (po.ly.an'ti.bi.o'ti.cus. Gr. adj. poly many; Gr. prep. anti against, in opposition to; Gr. n. bios life; L. suff. -icus - $a$-um suffix used in adjectives with the sense of belonging to, related to; N.L. masc. adj. polyantibioticus related to many antibiotics, referring to the ability to produce numerous antibiotics).
Produces brown substrate mycelium and fluffy, white aerial mycelium on inorganic salts-starch agar (ISP 4 medium). Leathery, dark-brown colonies are formed on ISP 2 medium, but no sporulation occurs. Brown substrate mycelium with white aerial mycelium is formed on oatmeal agar (ISP 3 medium). The colour of the substrate mycelium is not $\mathrm{pH}$ sensitive. Good growth is observed on Middlebrook 7H9-glucose agar with the formation of sporangia after prolonged incubation (90 days). A darkbrown, diffusible pigment is produced on glycerolasparagine agar (ISP 5 medium) and melanin is produced on peptone-yeast extract-iron agar (ISP 6 medium) and tyrosine agar (ISP 7 medium).

Grows in the presence of $0.1 \%$ (but not $0.3 \%$ ) 2phenylethanol, $0.0001 \%$ crystal violet, $7 \%$ (but not $10 \%) \mathrm{NaCl}$ and $0.1 \%$ phenol, but not in the presence of sodium azide $(0.01 \%)$. Growth is also observed in the presence of lysozyme, capreomycin $\left(20 \mu \mathrm{g} \mathrm{ml}^{-1}\right)$, cefotaxime $\left(100 \mu \mathrm{g} \mathrm{ml}^{-1}\right)$, cephaloridine $\left(100 \mu \mathrm{g} \mathrm{ml}^{-1}\right)$, D-cycloserine $\left(50 \mu \mathrm{g} \mathrm{ml}^{-1}\right)$, penicillin $\mathrm{G}\left(10 \mathrm{IU} \mathrm{ml}^{-1}\right)$ and viomycin $\left(8 \mu \mathrm{g} \mathrm{ml}^{-1}\right)$, but not in the presence of gentamicin $\left(100 \mu \mathrm{g} \mathrm{ml}^{-1}\right)$, kanamycin $\left(10 \mu \mathrm{g} \mathrm{ml}^{-1}\right)$, lincomycin $\left(100 \mu \mathrm{g} \mathrm{ml}^{-1}\right)$, neomycin $\left(50 \mu \mathrm{g} \mathrm{ml}^{-1}\right)$, oleandomycin $\quad\left(100 \mu \mathrm{g} \mathrm{ml}^{-1}\right), \quad$ rifampicin $\left(50 \mu \mathrm{g} \mathrm{ml}^{-1}\right)$, streptomycin $\left(100 \mu \mathrm{g} \mathrm{ml}^{-1}\right)$, tobramycin $\left(50 \mu \mathrm{g} \mathrm{ml}^{-1}\right)$ or vancomycin $\left(50 \mu \mathrm{g} \mathrm{ml}^{-1}\right)$. Growth occurs at 4 and $30{ }^{\circ} \mathrm{C}$ and at $\mathrm{pH} 4.3$, but not at $37^{\circ} \mathrm{C}$. Uses DL- $\alpha$-amino- $n$ butyric acid, L-arginine, L-cysteine, L-histidine, L-hydroxyproline, L-phenylalanine, potassium nitrate, L-serine, Lthreonine and L-valine as sole nitrogen sources; Lmethionine is weakly utilized. Uses $(+)$-D-cellobiose, $(-)$-D-fructose, (+)-D-galactose, (+)-D-glucose, myoinositol, $(-)$-D-lactose, $(+)$-D-mannose, $(+)$-D-melibiose, raffinose, salicin, sodium acetate $(0.1 \%)$, sodium citrate $(0.1 \%)$, trehalose and $(+)$-D-xylose as sole carbon sources [(-)-D-ribose is utilized weakly], but does not utilize adonitol, (+ )-L-arabinose, inulin, (-)-D-mannitol, (+)D-melezitose, $(+)$-L-rhamnose, sucrose or xylitol. 
$\mathrm{H}_{2} \mathrm{~S}$ is produced and nitrate is reduced (weakly). Lecithinase and lipase activity are observed on egg-yolk agar, but protease activity is not observed. Pectin is hydrolysed, but hippurate is not. Degrades adenine, aesculin, arbutin, casein, DNA, hypoxanthine, L-tyrosine, Tween 80 and xanthine, but not allantoin, cellulose, gelatin, guanine, starch, urea or xylan. Able to utilize the organic acids, sodium acetate, sodium citrate, sodium formate, sodium gluconate, sodium DL-lactate, sodium DLmalate, sodium succinate and sodium (+)-L-tartrate. Sodium butyrate is utilized weakly and sodium benzoate, sodium maleate, sodium mucate, sodium oxalate, sodium salicylate and sodium sorbate are not utilized.

The predominant menaquinones are MK- $9\left(\mathrm{H}_{4}\right)$ and MK$9\left(\mathrm{H}_{6}\right)$ and the phospholipids phosphatidylglycerol, phosphatidylethanolamine, phosphatidylinositol, phosphatidylinositol mannosides and diphosphatidylglycerol are detected. Very strong antibiosis is exhibited (in agar overlays) against Bacillus coagulans ATCC $7050^{\mathrm{T}}$, Enterococcus faecium VanA (a vancomycin-resistant clinical isolate), Enterococcus phoeniculicola JLB- ${ }^{\mathrm{T}}$, a Micrococcus species (clinical isolate), Mycobacterium aurum $\mathrm{A}+$ and a Streptococcus species (clinical isolate); weak activity is exhibited against Citrobacter braaki strain 90 (clinical isolate), Enterobacter cloacae strain 67 (clinical isolate), Escherichia coli ATCC 25922 and Klebsiella oxytoca strain K52 [clinical isolate; resistant to Augmentin and cefuroxime]. Five anti-M. aurum A + activity spots can be detected by bioautography of a methanol extract of the mycelial mass of a culture grown for 10 days with shaking at $30{ }^{\circ} \mathrm{C}$ in Hacène's medium [TLC, using ethyl acetate/methanol $(100: 15, \mathrm{v} / \mathrm{v})$ as the mobile phase].

The type strain, $\mathrm{SPR}^{\mathrm{T}}\left(=\mathrm{DSM} 44925^{\mathrm{T}}=\mathrm{NRRL} \mathrm{B}-24448^{\mathrm{T}}\right)$, was isolated from the banks of the Umgeni River in KwaZulu-Natal Province, South Africa. The DNA G+C content of the type strain is $74.4 \pm 0.2 \mathrm{~mol} \%(1.0 \times \mathrm{SSC})$.

\section{Acknowledgements}

We are grateful to Di James for DNA sequencing, to Miranda Waldron of the Electron Microscope Unit, University of Cape Town for help with scanning electron microscopy, to Madhu Chauhan for determining the DNA G + C content and to the Deutsche Sammlung von Mikroorganismen und Zellkulturen (Braunschweig, Germany) for the determination of the predominant menaquinones. We thank Hans G. Trüper for assistance with the Latin in deriving the specific epithet for strain $S R^{T}$. We are grateful to Vanessa Davids and Andrew Whitelaw for providing the clinical isolates. M. le R. holds a post-doctoral research fellowship from the University of Cape Town. P.M. is the recipient of research grants from the Medical Research Council of South Africa and the University Research Committee (University of Cape Town).

\section{References}

Altschul, S. F., Madden, T. L., Schäffer, A. A., Zhang, J., Zhang, Z., Miller, W. \& Lipman, D. J. (1997). Gapped BLAST and PSI-BLAST: a new generation of protein database search programs. Nucleic Acids Res 25, 3389-3402.
Anderson, A. S. \& Wellington, E. M. H. (2001). The taxonomy of Streptomyces and related genera. Int J Syst Evol Microbiol 51, 797-814.

Atlas, R. M. (2004). Handbook of Microbiological Media, 3rd edn. Edited by L. C. Parks. Boca Raton, FL: CRC Press.

Betina, V. (1973). Bioautography in paper and thin-layer chromatography and its scope in the antibiotic field. J Chromatogr 78, 41-51.

Chou, S., Chedore, P. \& Kasatiya, S. (1998). Use of gas chromatographic fatty acid and mycolic acid cleavage product determination to differentiate among Mycobacterium genavense, Mycobacterium fortuitum, Mycobacterium simiae and Mycobacterium tuberculosis. J Clin Microbiol 36, 577-579.

Chun, J. \& Goodfellow, M. (1995). A phylogenetic analysis of the genus Nocardia with 16S rRNA gene sequences. Int J Syst Bacteriol 45, 240-245.

Chun, J., Lee, J.-H., Jung, Y., Kim, M., Kim, S., Kim, B. K. \& Lim, Y. W. (2007). EzTaxon: a web-based tool for the identification of prokaryotes based on $16 \mathrm{~S}$ ribosomal RNA gene sequences. Int J Syst Evol Microbiol 57, 2259-2261.

Chung, Y. R., Sung, K. C., Mo, H. K., Son, D. Y., Nam, J. S., Chun, J. \& Bae, K. S. (1999). Kitasatospora cheerisanensis sp. nov., a new species of the genus Kitasatospora that produces an antifungal agent. Int J Syst Bacteriol 49, 753-758.

Cook, A. E. \& Meyers, P. R. (2003). Rapid identification of filamentous actinomycetes to the genus level using genus-specific $16 \mathrm{~S}$ rRNA gene restriction fragment patterns. Int J Syst Evol Microbiol 53, 1907-1915.

Euzéby, J. (2008). List of prokaryotic names with standing in nomenclature. http://www.bacterio.cict.fr/

Goodfellow, M. (1989). Maduromycetes. In Bergey's Manual of Systematic Bacteriology, vol. 4, pp. 2509-2551. Edited by S. T. Williams, M. E. Sharpe \& J. G. Holt. Baltimore: Williams \& Wilkins.

Gordon, R. E., Barnett, D. A., Handerhan, J. E. \& Pang, C. H.-N. (1974). Nocardia coeliaca, Nocardia autotrophica, and the nocardin strain. Int J Syst Bacteriol 24, 54-63.

Groth, I., Vettermann, R., Shuetze, B., Schumann, P. \& SaizJimenez, C. (1999). Actinomycetes in Karstic caves of northern Spain (Altamira and Tito Bustillo). J Microbiol Methods 36, 115-122.

Groth, I., Schütze, B., Boettcher, T., Pullen, C. B., Rodriguez, C., Leistner, E. \& Goodfellow, M. (2003). Kitasatospora putterlickiae sp. nov., isolated from rhizosphere soil, transfer of Streptomyces kifunensis to the genus Kitasatospora as Kitasatospora kifunensis comb. nov., and emended description of Streptomyces aureofasciens Duggar 1948. Int J Syst Evol Microbiol 53, 2033-2040.

Hacène, H. \& Lefebvre, G. (1995). AH17, a new non-polyenic antifungal antibiotic produced by a strain of Spirillospora. Microbios 83, 199-205.

Hasegawa, T., Takizawa, M. \& Tanida, S. (1983). A rapid analysis for chemical grouping of aerobic actinomycetes. J Gen Appl Microbiol 29, 319-322.

Kim, B., Al-Tai, A. M., Kim, S. B., Somasundaram, P. \& Goodfellow, M. (2000). Streptomyces thermocoprophilus sp. nov., a cellulose-free endoxylanase-producing streptomycete. Int J Syst Evol Microbiol 50, 505-509.

Kim, S. B., Seong, C. N., Jeon, S. J., Bae, K. S. \& Goodfellow, M. (2004). Taxonomic study of neutrotolerant acidophilic actinomycetes isolated from soil and description of Streptomyces yeochonensis sp. nov. Int J Syst Evol Microbiol 54, 211-214.

Klappenbach, J. A., Dunbar, J. M. \& Schmidt, T. M. (2000). rRNA operon copy number reflects ecological strategies of bacteria. Appl Environ Microbiol 66, 1328-1333.

Komagata, K. \& Suzuki, K.-I. (1987). Lipid and cell-wall analysis in bacterial systematics. Methods Microbiol 19, 161-207. 
Kumar, S., Tamura, K. \& Nei, M. (2004). MEGA3: integrated software for molecular evolutionary genetics analysis and sequence alignment. Brief Bioinform 5, 150-163.

Li, W., Lanoot, B., Zhang, Y., Vancanneyt, M., Swings, J. \& Liu, Z. (2002). Streptomyces scopiformis sp. nov., a novel streptomycete with fastigiate spore chains. Int J Syst Evol Microbiol 52, 1629-1633.

Li, W. J., Zhang, Y. G., Zhang, Y. O., Tang, S. K., Xu, P., Xu, L. H. \& Jiang, C. L. (2005). Streptomyces sodiiphilus sp. nov., a novel alkaliphilic actinomycete. Int J Syst Evol Microbiol 55, 1329-1333.

Locci, R. (1989). Streptomyces and related genera. In Bergey's Manual of Systematic Bacteriology, vol. 4, pp. 2451-2508. Edited by S. T. Williams, M. E. Sharpe \& J. G. Holt. Baltimore: Williams \& Wilkins.

Mandel, M. \& Marmur, J. (1968). Use of ultraviolet absorbancetemperature profile for determining the guanine plus cytosine content of DNA. In Methods in Enzymology, vol. 12, pp. 195-206. Edited by L. Grossman \& K. Moldave. New York: Academic Press.

Minnikin, D. E., Alshamaony, L. \& Goodfellow, M. (1975). Differentiation of Mycobacterium, Nocardia, and related taxa by thin-layer chromatographic analysis of whole-organism methanolysates. J Gen Microbiol 88, 200-204.

Minnikin, D. E., O'Donnell, A. G., Goodfellow, M., Alderson, G., Athalye, M., Schaal, A. \& Parlett, J. H. (1984). An integrated procedure for the extraction of bacterial isoprenoid quinones and polar lipids. J Microbiol Methods 2, 233-241.

Ping, X., Takahashi, Y., Seino, A., Iwai, Y. \& Omura, S. (2004). Streptomyces scabrisporus sp. nov. Int J Syst Evol Microbiol 54, 577581.

Saitou, N. \& Nei, M. (1987). The neighbor-joining method: a new method for reconstructing phylogenetic trees. Mol Biol Evol 4, 406425.
Sambrook, J., Fritsch, E. F. \& Maniatis, T. (1989). Bacterial media, antibiotics and bacterial strains. In Molecular Cloning, a Laboratory Manual, 2nd edn, Appendix A, pages A1 and A4. Cold Spring Harbor, NY: Cold Spring Harbor Laboratory.

Schleifer, K. H. \& Kandler, O. (1972). Peptidoglycan types of bacterial cell walls and their taxonomic implications. Bacteriol Rev 36, 407-477.

Shirling, E. B. \& Gottlieb, D. (1966). Methods for characterization of Streptomyces species. Int J Syst Bacteriol 16, 313-340.

Shirling, E. B. \& Gottlieb, D. (1972). Cooperative description of type strains of Streptomyces. Int J Syst Bacteriol 22, 265-394.

Skarbek, J. D. \& Brady, L. R. (1978). Streptomyces cavourensis sp. nov. (nom. rev.) and Streptomyces cavourensis subsp. washingtonensis subsp. nov., a chromomycin-producing subspecies. Int J Syst Bacteriol 28, 45-53.

Takahashi, K. \& Nei, M. (2000). Efficiencies of fast algorithms of phylogenetic inference under the criteria of maximum parsimony, minimum evolution, and maximum likelihood when a large number of sequences are used. Mol Biol Evol 17, 1251-1258.

Waksman, S. A. \& Henrici, A. T. (1943). The nomenclature and classification of the actinomycetes. J Bacteriol 46, 337-341.

Wang, Y. \& Zhang, Z. (2000). Comparative sequence analyses reveal frequent occurrence of short segments containing an abnormally high number of non-random base variations in bacterial rRNA genes. Microbiology 146, 2845-2854.

WHO (2008). Report: Global Tuberculosis Control. http:// www.who.int

Xu, P., Li, W.-J., Wu, W.-L., Wang, D., Xu, L.-H. \& Jiang, C.-L. (2004). Streptomyces hebeiensis sp. nov. Int J Syst Evol Microbiol 54, 727731. 